\title{
ZAKAT DAN WAKAF SEBAGAI PILAR DALAM SISTEM \\ PEREKONOMIAN NASIONAL
}

\author{
Oleh: \\ Mustafa Edwin Nasution *
}

\begin{abstract}
Abstrak
In Islamic teaching, philanthropy plays a significant role which is equal to other worships. It can be seen through the zakat position in arkanul Islam that hold the $3^{\text {rd }}$ rank after syahadah and sholat. Zakat and wakaf are not only the parts of Islamic Philanthropy aimed to make poor people well improved, but also the parts of state's policy that can be used to support the development of economy.
\end{abstract}

Keyword: zakat, wakaf, Islamic Philanthropy

\section{PENDAHULUAN}

Is lam sebagai agama rahmatan lil alamin adalah ajaran yang menghendaki kebaikan bagi sekalian alam. Untuk menjaga keseimbangan dan kebaikan tersebut, Allah menetapkan segala sesuatunya dengan syariat, yang termaktub dari al quran dan hadits.

Salah satu aturan yang digariskan Allah adalah mengenai masalah kepemilikan harta. Al Quran menekankan bahwa kepemilikan harta bagi manusia sifatnya merupakan titipan dari Allah, dan bukan kepemilikan yang sifatnya absolut. Kepemilikan harta yang sifatnya titipan ini berimplikasi pada banyak hal. Salah satunya adalah konsep filantropi dalam sistem ekonomi Islam.

Dalam ajaran Islam, filantropi menjadi suatu kegiatan yang sama pentingnya dengan ibadah-ibadah lainnya. Hal ini bisa kita lihat dari kedudukan zakat yang menjadi rukun Islam ketiga, menjadi ibadah wajib yang harus dilakukan setelah sholat. Dari kedudukan zakat dalam rukun Islam ini sangat jelas 
bahwa Islam merupakan agama yang sangat mengedepankan filantropi. Kewajiban berfilantropi ini juga terlihat dari banyaknya ayat-ayat dalam al Quran maupun hadits rasulullah SAW yang berbicara tentang masalah tersebut. Dalam Al-Qur'an terdapat 82 ayat yang mensejajarkan shalat dengan kewajiban zakat, dan satu kali disebutkan dalam konteks yang sama akan tetapi dalam ayat berbeda, yaitu Surat Al-Mukminun ayat 2 dengan ayat 4 (Yusuf Qardhawi, Fiqh Zakat, 1973).

Komponen filantropi dalam Islam dapat dikategorikan kepada 2 bagian besar, yaitu yang sifatnya wajib dan yang sifatnya tidak wajib atau sunnah. Untuk filantropi yang sifatnya wajib ini adalah zakat, sedangkan untuk filantropy yang sifatnya sunnah ini antara lain; sedekah, infaq, wakaf.

Jika berbicara mengenai masalah potensi filantropi, maka mestinya Indonesia memiliki potensi besar untuk masalah ini. Bagaimana tidak? Indonesia adalah negara dengan jumlah penduduk beragama muslim terbesar di dunia. Namun, apalah artinya potensi jika realita yang ada jauh dari apa yang diharapkan. Meski demikian, secara normatif kita dapat mengoptimalkan dana zakat dan wakaf di Indonesia, memaksimalkan pengelolaannya sehingga memiliki manfaat dalam roda pembangunan bangsa ini.

Harapan yang besar akan potensi zakat dan wakaf ini kiranya bukan sesuatu yang berlebihan mengingat wakaf dan zakat pada masa pemerintahan Rasulullah, Khulafaur Rasyidin dan juga dinasti Islam dapat dimanfaatkan sedemikian rupa sehingga terjadi pertumbuhan ekonomi yang spektakuler dan sangat hebat di jamannya. Pada masa pemerintahan Rasulullah dalam waktu 10 
tahun telah berdiri suatu negara Madinah yang dapat dikatakan negara yang relatif makmur. Bahkan pada masa pemerintahan Umar bin Abdul Aziz tidak ditemukan lagi penduduk yang mau menerima zakat karena semua sudah mampu.

Makalah ini secara singkat akan mencoba memaparkan peran zakat dan wakaf dalam suatu sistem perekonomian. Dengan mengacu kepada keberhasilan pengelolaan zakat dan wakaf di masa lampau dan juga dengan melihat fungsinya ke depan dalam suatu sistem perekonomian.

\section{Kedudukan Zakat dan Wakaf dalam Islam: Instrumen Distribusi}

Berbeda dengan sistem ekonomi kapitalis yang memberikan kebebasan kepada individu untuk mengakumulasi kapital tanpa batasan nilai moral, etika dan juga norma-norma lainnya, ekonomi islam tidak membenarkan kebebasan mutlak yang bersifat memperkaya atau pun menguntungkan diri sendiri. Larangan ini begitu nyata dalam surat Al Hasyr ayat 7, dimana disebutkan “....jangan sampai harta yang ada hanya beredar pada golongan kaum tertentu”. Meski demikian, berbeda dengan sistem ekonomi sosialis, Islam juga tidak mematikan kepemilikan hak individu. Hak individu tetap diakui sesuai dengan porsinya, sesuai dengan hasil usaha dan kerja kerasnya.

Pengakuan akan hak individu dan prinsip keadilan dalam Islam berimplikasi pada perbedaan kepemilikan antara seseorang dengan orang lain. Perbedaan kepemilikan juga diakibatkan oleh faktor rezeki, dimana tiap orang memiliki rezeki yang berbeda. Sebagaimana janji Allah, sebahagian dari hambaNya, ada yang disempitkan rezekinya dan ada juga yang diluaskan. Namun 
perbedaan dalam hal kepemilikan ini tidak berarti bahwa mereka yang memiliki kelapangan rezeki menjadi tidak memiliki kewajiban apa pun terhadap mereka yang kekurangan.

Dalam upaya menciptakan keadilan dan kesejahteraan, Islam pun memberi banyak kesempatan bagi masyarakat mampu untuk mendistribusikan pendapatannya kepada mereka yang tidak mampu. Hal ini dilihat dari banyaknya instrumen yang dapat digunakan dalam kegiatan distribusi tersebut. Zakat dan Wakaf adalah salah satu instrumen yang dapat digunakan untuk proses distribusi pendapatan tersebut.

Meskipun pada dasarnya zakat dan wakaf berbeda dari segi mekanisme pelaksanaan dan aturan namun secara fungsional esensinya kedua lembaga filantropi ini tidak berbeda. Bahkan jika dilakukan penggalangan secara sinergis, keduanya akan saling melengkapi dalam upaya-upaya pemberdayaan masyarakat marginal.

Wakaf, yang asal katanya berarti menahan, secara bahasa dapat diartikan sebagai penahanan atau pelestarian harta benda tertentu untuk kepentingan dan tujuan mulia lainnya. Dari definisi wakaf ini jelas terlihat makna kata wakaf yang mengindikasikan sifat tahan lama atau abadi dari harta benda yang diwakafkan. Sehingga dari proses menahan sesuatu inilah hasil wakaf dapat digunakan untuk sejumlah kebaikan.

Pengalokasian dana wakaf biasanya diperuntukkan untuk sarana/prasarana yang mendukung kegiatan keIslaman dalam bentuk rumah ibadah. Jenis wakaf ini termasuk dalam jenis wakaf pertama, yaitu wakaf yang peruntukkannya ditujukan 
untuk membangun rumah ibadah ataupun fasilitas keagamaan lainnya. Wakaf lainnya adalah wakaf yang peruntukannya digunakan untuk membangun fasilitas umum (jembatan, sekolah, rumah sakit, penelitian, dan lainnya). Jenis wakaf ini termasuk dalam jenis kedua yang dikenal dengan jenis wakaf filantropi, yaitu ditujukan untuk mendukung masyarakat miskin dan kepentingan umum secara menyeluruh. Untuk wakaf jenis ketiga, biasanya diperuntukkan untuk keluarga yang masih menjadi ahli waris dari pemilik harta yang meninggal. Dengan demikian jika kita menilik definisi wakaf dan juga contoh peruntukannya maka kita dapat mengalokasikan wakaf untuk membangun fasilitas keagamaan maupun fasilitas pendukung kegiatan kemasyarakatan dan pembangunan lainnya. Saat ini, dikembangkan juga jenis wakaf tunai. Wakaf tunai sebagai dana abadi ini dalam pengelolaan lebih fleksibel. Di Bangladesh, dan beberapa negara timur tengah lainnya seperti Turki dan Kuwait, wakaf tunai telah dikembangkan sebagai instrumen dalam usaha pengentasan kemiskinan.

Berbeda dengan wakaf, dimana harta yang diwakafkan harus ditahan atau harus diabadikan, maka tidak demikian halnya dengan dana zakat. Dana zakat sebagaimana tercantum dalam Al Quran dialokasikan untuk kepentingan mustahik atau penerima zakat. Berbeda dengan dana wakaf yang lebih banyak diperuntukkan pada pembangunan fasilitas yang sifatnya fisik, maka peruntukan dana zakat pada lebih banyak diperuntukkan kepada bantuan untuk pengentasan kemiskinan, pengembangan SDM dan juga bantuan modal usaha bagi pengusaha kecil menengah, penciptaan lapangan kerja dan lainnya. 


\section{Peran Strategis Zakat dan Wakaf di Masyarakat: Success Story}

Keberhasilan pengelolaan zakat dan wakaf telah dibuktikan pada masa pemerintahan Rasulullah SAW, Khulafaur Rasyidin dan juga Khilafah di zaman dinasti islam lainnya. Dalam suatu riwayat disebutkan bahwa pada masa pemerintahan Umar bin Abd Aziz, tidak ditemukan lagi masyarakat yang layak untuk menerima zakat, karena semua telah mampu menjadi muzakki, sehingga zakat yang ada dibagikan kepada masyarakat di negara lain.

Keberhasilan zakat tidak hanya terjadi pada masa keemasan dinasti Islam, namun juga dapat dibuktikan sampai dengan saat ini. Demikian juga halnya dengan wakaf. Di negara-negara arab yang telah mengelola wakaf secara profesional, wakaf berkembang sedemikian pesat, sehingga hasil yang dapat kita lihat antara lain sekolah Al Azhar yang ada di Kairo. Di Indonesia sendiri wakaf banyak dikembangkan dalam bentuk yayasan. Salah satunya adalah yayasan pondok pesantren Gontor.

Kuran, 2001 menyebutkan bahwa wakaf dalam Islam muncul sebagai sarana komitmen yang dapat dipercaya untuk memberikan keamanan bagi pemilik harta sebagai imbangan dari layanan sosial yang diberikan. Penelitian yang dilakukan di Timur Tengah ini juga mencatat bahwa wakaf telah lama berfungsi sebagai instrumen penting untuk memberikan public goods dengan cara yang tidak sentralistik.

Penelitian lain tentang wakaf diungkapkan oleh R.D McChesney (1991) yang menulis buku hasil penelitiannya tentang kegiatan wakaf di Asia Tengah selama 400 tahun. Disebutkan bahwa wakaf telah menjadi pusat penting 
kehidupan umat Islam sehari-hari dalam kurun waktu yang lama. Banyak peran yang telah dijalankan oleh institusi wakaf ini, seperti membangun lembagalembaga keagamaan, kultural dan kesejahteraan dan menjadi sarana sah dalam menjaga keutuhan kekayaan keluarga dari satu generasi ke generasi berikutnya. Hasil penelitian ini juga menunjukkan bagaimana peran wakaf berfluktuasi sejalan dengan sikap pemerintah sebagai penguasa.

Pada saat sebagian besar negara-negara muslim dibawah kekuasaan penjajahan barat, suasana suram menyelimuti institusi wakaf di negara-negara tersebut. Pada saat yang sama, terlihat kemunduran yang signifikan di dunia muslim. Namun kondisi segera berubah dengan merdekanya sebagian negara mus lim pada abad ke-20. Kemerdekaan ini serta merta membawa perubahan besar pada manajemen pengelolaan wakaf di negara-negara tersebut. Sebagai contoh sejumlah harta wakaf di Syria, Mesir, Turki, Tunis dan Aljazair dialihkan menjadi harta publik yang diawasi oleh negara dan didistribusikan melalui land reforms dan lainnya. Beberapa negara menciptakan Undang-undang wakaf dan mendirikan departemen wakaf untuk memajukan institusi tersebut di negaranya. Dari sejumlah paparan di atas, jelas terlihat bahwa wakaf berperan signifikan dalam menentukan maju atau mundurnya suatu komunitas masyarakat.

\section{Potensi Zakat dan Wakaf di Indonesia}

Cerita mengenai sukses zakat dan wakaf di masa-masa yang lalu, pada akhirnya akan mengantarkan kita pada pertanyaan bagaimana dengan kondisi zakat dan wakaf di Indonesia? Indonesia dengan negara muslim terbesar, idealnya 
akan mampu mengumpulkan dana zakat dan wakaf yang besar.

Untuk melihat seberapa besar potensi zakat dan wakaf di Indonesia, perlu dilakukan perhitungan. Perhitungan potensi zakat telah banyak dilakukan dengan asumsi yang berbeda. Pada kesempatan ini maka perhitungan potensi yang dilakukan dengan mengasumsikan bahwa besaran zakat yang diterapkan adalah 2,5\% dan asset masyarakat muslim dari total PDB sebesar 20\%. Adapun hasil selengkapnya dapat dilihat dalam Tabel 1.

Tabel 1. PDB Indonesia dan Perhitungan Potensi Zakat

\begin{tabular}{|c|c|c|}
\hline Tahun & PDB (milyar) & Potensi Zakat (Trilyun) \\
\hline 2002 & 1505216 & 7.5 \\
\hline 2003 & 1577171 & 8.9 \\
\hline 2004 & 1656826 & 8.7 \\
\hline 2005 & 1749547 & 8.3 \\
\hline
\end{tabular}

Sumber: Data BPS, diolah

Untuk potensi wakaf, perhitungan dapat dilakukan secara sederhana dengan mengasumsikan jumlah muslim kelas menengah sebanyak 10 juta jiwa dengan rata-rata penghasilan per bulan Rp 500.000 hingga Rp 10.000.000 (sepuluh juta). Masing-masing kelompok muslim dengan tingkat pendapatan yang berbeda ini diasumsikan menjadi pelanggan rutin sertifikat wakaf tunai tiap bulannya, sehingga perhitungan yang dapat dilakukan adalah sebagaimana terlihat dalam Tabel 2. Potensi Wakaf Tunai di Indonesia. 
Tabe12. Potensi Wakaf Tunai di Indonesia

\begin{tabular}{|l|l|l|l|l|}
\hline $\begin{array}{l}\text { Tingkat } \\
\text { Penghasilan/bulan }\end{array}$ & $\begin{array}{l}\text { Jumlah } \\
\text { Muslim }\end{array}$ & $\begin{array}{l}\text { Tarif } \\
\text { Wakaf/Bulan }\end{array}$ & $\begin{array}{l}\text { Potensi Wakaf } \\
\text { Tunai/Bulan }\end{array}$ & $\begin{array}{l}\text { Potensi Wakaf } \\
\text { Tunai/Tahun }\end{array}$ \\
\hline Rp 500.000 & 4 juta & Rp 5000 & Rp 20 Milyar & Rp 240 Milyar \\
\hline Rp 1-2 juta & 3 juta & Rp 10000 & Rp 30 Milyar & Rp 360 Milyar \\
\hline Rp 2-5 juta & 2 juta & Rp 50000 & Rp 100 Milyar & Rp 1,2 Trilyun \\
\hline Rp 5-10 juta & 1 juta & Rp 100.000 & Rp 100 M & Rp 1,2 Trilyun \\
\hline Total & & 3 Trilyun \\
\hline
\end{tabular}

Sumber: Wakaf Tunai Inovasi Finansial Islam (Nasution, 2005)

Berdasarkan data potensi zakat maupun wakaf, keduanya memiliki nilai dengan besaran yang mengagumkan. Terlebih jika potensi itu dapat diwujudkan maka nilainya akan sangat bermanfaat bagi program-program pengentasan kemiskinan di Indonesia.

Secara aktual, jika potensi ini kita sandingkan dengan data realisasi penghimpunan zakat yang berhasil dikumpulkan oleh pihak LAZ atau BAZ, maka kesenjangan yang terjadi cukup besar. Data Forum Zakat (FOZ) menunjukkan bahwa total zakat ditambah sedekah dan infak yang berhasil dikumpulkan oleh pihak LAZ dan BAZ pada tahun 2005 hanya mencapai 250 Milyar.

Untuk mencapai potensi ini tentunya perlu kerja keras dan juga political will dari pemerintah. Tanpa adanya political will dari pemerintah tentunya upaya mencapai potensi ini akan lebih sulit diwujudkan. Sebagai kasus, untuk program keluarga berencana $(\mathrm{KB})$ yang saat ini hampir dikatakan sukses - terlihat dari rata-rata kepemilikan anak saat ini yang berjumlah 2-3 orang - butuh waktu 
sekitar 30 an tahun. Kasus ini juga memberi inspirasi kepada kita untuk tidak berputus as a ketika perolehan zakat belum sampai pada nilai potensinya.

\section{Peran Zakat dan Wakaf dalam Pe rekonomian}

Pengalaman sejarah tentang pentingnya zakat dan wakaf dalam masyarakat tentunya menjadi lesson learned bagi pemerintah untuk mengembangkan kedua institusi ini. Sinergi dari kedua institusi ini tentunya bisa menjadi solusi bagi sejumlah masalah-masalah perekonomian seperti pengentasan kemiskinan, pengangguran, pengadaan fasilitas publik dan sebagainya.

Upaya memberdayakan zakat dan wakaf tentunya merupakan suatu rangkaian yang saling terkait dari proses sosialisasi ke masyarakat, pengumpulan zakat, profesionalitas dan akuntabilitas serta efektifitas dari pengelolaan dana zakat dan wakaf tersebut. Jika salah satu dari mata rantai ini terputus, maka kegiatan pemberdayaan otomatis akan menghambat proses pemberdayaan itu sendiri.

Untuk mengoptimalkan pengumpulan zakat dan wakaf dari masyarakat, Lembaga Amil Zakat (LAZ) perlu untuk menerapkan sejumlah strategi pemasaran. Penerapan bauran pemasaran sebagaimana dikemukakan oleh Kottler (2000), dapat diterapkan dalam upaya meningkatkan realisasi penerimaan zakat dan wakaf dari masyarakat. Lebih jauh, intervensi pemerintah dalam memobilisasi dana wakaf dan zakat ini akan berperan penting dalam mengumpulkan dana zakat dan wakaf ini. Selain itu, profesionalitas lembaga pengumpul zakat dan transparansi merupakan dua hal yang tidak boleh tidak 
harus diterapkan oleh lembaga amil zakat.

Salah satu profesionalitas kelembagaan dicirikan dari bagaimana lembaga itu mengalokasikan dana wakaf dan zakat secara efektif. Efektifitas program ataupun pengalokasian dari pengelolaan dana dan wakaf dapat dinilai dari sejauh mana program-program yang dibuat oleh lembaga amil zakat (LAZ) atau BAZ bermanfaat bagi masyarakat.

Jika kita lihat perbedaan aturan mengenai wakaf dan zakat, maka manajemen pengelolaan keduanya pun harus berbeda pula. Namun kita dapat memanfaatkan keduanya untuk program-program pemberdayaan masyarakat sehingga menunjang aktifitas perekonomian. Untuk zakat misalnya, dapat dimanfaatkan untuk program padat karya dan bantuan modal untuk masyarakat miskin, pendidikan dan pengobatan gratis untuk masyarakat tidak mampu, bantuan modal untuk pengusaha terutama kelompok kecil dan mikro bahkan jika dimungkinkan menjadi penjamin bagi kelompok usaha kecil dan mikro untuk dapat akses terhadap pembiayaan dari perbankan, mengingat salah satu hambatan dari pelaku usaha kecil untuk dapat akses kepada pembiayaan dari perbankan adalah ketiadaan jaminan dan ketidaklayakan usaha.

Adanya program padat karya, bantuan pendidikan gratis dan juga pembuka akses terhadap modal ini akan berdampak luas dalam sistem perekonomian nasional. Setidaknya akan meningkatkan konsumsi dari masyarakat tidak mampu, dimana hal ini merupakan suatu isu yang saat ini tengah dirintis oleh sejumlah pakar ekoknomi, yaitu bagaimana mengikutsertakan kelompok miskin ini kedalam suatu sistem perekonomian. Karena dengan ikutsertanya masyarakat miskin dalam 
sistem pasar, hal ini akan meningkatkan aktivitas perekonomian baik dari sisi produksi maupun konsumsi.

Berbeda dengan zakat yang peruntukannya secara khusus ditujukan pada 8 asnaf, maka untuk pengelolaan wakaf diterapkan perlakuan khusus. Hal ini karena aturan wakaf menghendaki adanya keabadian dari harta yang diwakafkan. Sebagaimana dengan pengalaman di masa yang lalu dimana dana wakaf lebih banyak diperuntukkan pada pengadaan fasilitas publik seperti mesjid, sekolah/madrasah, rumah sakit dan fasilitas umum lainnya.

Kegiatan wakaf ke depan lebih banyak diarahkan dalam bentuk wakaf tunai. Dibandingkan dengan wakaf yang berwujud harta benda, wakaf tunai lebih fleksibel baik dalam pengumpulan maupun dalam pemanfaatannya. Wakaf tunai, memberikan akses yang lebih besar kepada masyarakat untuk berwakaf tanpa harus memiliki uang yang banyak untuk membeli tanah maupun mendirikan bangunan. Dalam pengelolaannya pun relatif lebih fleksibel. Wakaf tunai dapat diinvestasikan ke sejumlah investasi produktif yang hasilnya dapat dimanfaatkan untuk usaha-usaha pengentasan kemiskinan, pengadaan fasilitas publik seperti sekolah, rumah sakit, jalan, jembatan dan lainnya.

Dari sudut pandang ekonomi, kedua hal ini memiliki dampak yang sangat luar biasa. Kegiatan investasi dari wakaf tunai, berdampak besar pada pergerakan sektor riil perekonomian. Value lain terlihat dari multiplier efek dari keuntungan investasi yang digunakan untuk usaha pengentasan kemiskinan dan pengadaan fasilitas publik.

Berdasarkan uraian tentang sejumlah manfaat keberadaan institusi zakat 
dan wakaf ini terlihat bahwa baik zakat dan wakaf tidak hanya sekedar kegiatan filantropi yang mengangkat kehidupan kaum dhuafa. Kedua institusi ini memiliki dampak yang luar biasa terhadap pergerakan dan pertumbuhan sektor riil perekonomian. Kondisi ini bertolak belakang dengan sistem ekonomi pasar yang saat ini cenderung berinvestasi di pasar uang dan pasar modal, yang mengakibatkan pertumbuhan semu perekonomian atau bubble economic. 


\section{DAFTAR PUSTAKA}

Ali, Mohammad Daud, " Sistem Ekonomi Islam Zakat dan Wakaf ", UI-Press, Jakarta, 1988

Badan Pusat Statistik, " Analisis dan Penghitungan Tingkat Kemiskinan Tahun 2005 "

Badan Pusat Statistika, "Statistik Indonesia “, 2005

Chapra, Umer, " The Future of Economics : An Islamic Perspective " SEBI, Jakarta, 2001

Mannan, M.A, “Sertifikat Waqf Tunai : Sebuah Inovasi Instrumen Keuangan Islam “, PKTTI-UI, Jakarta, 2001

Nasution, Mustafa Edwin " Wakaf Tunai Inovasi Finansial Islam " PKTTI-UI, Jakarta, 2005

Nasution, Mustafa Edwin, Yusuf Wibisono " Zakat Sebagai Instrumen Pengentasan Kemiskinan", Proceeding Muktamar IAEI , Medan, 2005

* Mustafa Edwin Nasution, Ph.D, Dosen Pascasarjana Unive rsitas Indonesia 